\title{
Medico-legal Relation between Children abuse and child labor in Great Cairo governorate, Egypt
}

\author{
Nancy Mohamed Zaghloul ${ }^{1}$; Sherif ahmed Hetta ${ }^{2}$ and Nazih Ramadan ${ }^{3}$ \\ ${ }^{1}$ Department of Forensic Medicine \& Clinical Toxicology, Faculty of Medicine, Misr university of science \\ and technology (MUST), Egypt \\ ${ }^{2}$ Department of comunity Medicine, Faculty of Medicine, Misr university of science and technology (MUST), \\ Egypt \\ ${ }^{3}$ Department of Forensic Medicine \& Clinical Toxicology, Faculty of Medicine, Cairo university, Egypt
}

Corresponding Author:

Nazih Ramadan; Department of Forensic Medicine and Clinical Toxicology, Faculty of Medicine, Cairo University, Egypt.

Email: drnazihramadan@ kasralainy.edu.eg Tel: 01127448261

\begin{abstract}
Background: Over the past several years, some forms of violence against children including; the sexual exploitation and trafficking, female genital mutilation, child labor and impact of armed conflict, have led to international provocation. The international community has unanimously condemned all forms of child abuse. However many children are subjected to physical, sexual and psychological violence in their homes, schools, at work and in their communities. All of which have devastating consequences for their current and future health and well-being.

Methods: Six hundred children randomly participated from randomly selected areas; 357 (59.5 $\%)$ males and $243(40.5 \%)$ females, the children ages ranged from 5 to 17 years. All study samples were subjected to interview questionnaire.

Results: The majority of working children was illiterates (68\%) and belonged to 48.67 and 45.67 $\%$ of non-educated fathers and mothers, respectively. Most of the working children were engaged in jobs at peddlers (33.33\%), followed by garage guard (16.67\%). Children aged from 11-15 Years are the most common group of children joined the work with a percentage of $81 \%$. Of all participants, $54 \%$ suffer from emotional abuse, about $24 \%$ of working children suffer from physical abuse, while $15 \%$ suffer from negligence and $7.5 \%$ suffer from sexual abuse

Conclusions: The study concluded that working children are more vulnerable to many abuses and abusive practices from employers. Illiteracy of both parents and children themselves and families of large number are the driving forces of child labor in the Great Cairo governorate.

Keywords: child abuse, child labor, Egypt, Great Cairo

\section{INTRODUCTION}

Child labor is considered as a serious global issue which is associated with many

factors such as poverty, gender inequality and illiteracy. Worldwide, around 168 million children $(11 \%$ of the child population) are engaged in a work, according to International Labor
\end{abstract}


Organization (ILO). In Egypt, about $8.3 \%$ of children aging 10-14 years were working according to the same organization(Mohammed et al., 2014). However, the National Council for Childhood and Motherhood proved that there are 2.76 million working children In Egypt, accounting for about $26 \%$ of children aged 16-14 years (Ali, 2019).

In Egypt, a child is considered in child labor, according to The Egyptian Child Labor Law, when he or she is under the age of 17 and engaged to work (Mohammed et al., 2014).

The concept of child labor is the work that places a heavy burden on the child, which threatens his safety, health and wellbeing. This is the work that benefits from the child's weakness and inability to defend his rights. It is also the work that exploits children as cheap labor alternative to adult labor. Child labor is the work that uses the presence of children and does not contribute to their development and impedes the education and training of the child and changes his life and future (Hindman, 2009).

The work in young ages has many hazards, first it deprives children of their childhood, dignity and potential, it also affects their physical and mental development and they are more exposed to physical or sexual abuse. Moreover, it requires them to exert more efforts to combine school attendance with their work (Homaie Rad et al., 2015).

In fact, there is no one definite definition or set of definitions for child abuse or child maltreatment and neglect. Child abuse includes; acts of physical abuse, physical injury, shaken baby syndrome, sexual abuse, emotional abuse and exploitation, emotional injury, and institutional abuse. On the other hand, Child Neglect includes many forms; the failure to provide for a child's basic human needs of food, shelter, clothing, supervision, opportunity to grow up healthy, in addition to emotional, educational, medical, psychological and social neglect, and failure to thrive (Sealey, 2015).

Child physical abuse can be defined as acts causing or at least have the potential to cause physical harm. The extent of physical abuse range from mild/moderate physical maltreatment (e.g. skin injury and fractures of bones) to fatal abuse leading to death (Elsaied \& Alsehly, 2017). The World Health Organization has defined child sexual abuse as: "The involvement of a child in sexual activity that he or she does not fully comprehend, is unable to give informed consent to, or for which the child is not developmentally prepared, or that violates the laws or social taboos of society (Radwan et al., 2019). In fact, child abuse is an important decipline of Family violence which is "the inflicting of physical injury by one family or household member on another (EL-Gendy et al., 2016).

A review of existing research may give idea that there is information gap about child abuse among working children which needs to be addressed and highlighted. In developing societies, awareness about child abuse is less recognized as a major social or public health problem. Therefore, the documentation of the prevalence of abuse is expected to be poor (Hadi, 2000).

Egyptian Foundation for Advancement of Childhood Conditions (EFACC) reported in its monthly report that March 2017 witnessed the highest rates of child abuse in Egypt over the past five years. In March alone, at least 1,112 children were 
subjected to various abuses, including murder, abduction, rape, drowning and other cases. The figures showed that $13 \%$ of the cases involved girls and $16 \%$ boys; no gender was identified in $71 \%$ of the cases(Shafik et al., 2019).

\section{AIM OF THE STUDY}

The present study aims to know the patterns of perceived abuse experienced by child workers within and outside the family and the rate of each pattern. In addition, to evaluate the relation between child abuse and variable educational level of the parents and the employer and other socioeconomic factors.

\section{PARTICIPANTS AND METHODS}

\section{- Study Approach}

The approach used in this study is the questionnaire-based approach. The relationship between physical and psychological abuse and neglect in childhood is identified in terms of early child labor, as well as a description of the relationship between the socioeconomic and educational level of parents and employers and perceived abuse of working children.

\section{- Study population}

The study population was working children in different fields of work in areas of great Cairo, Egypt.

- The study sample

The sample was tested in a simple random way among children working in areas of great Cairo, Egypt, in period between January and June, 2018 with minimum number 500 children.

_ Inclusion criteria:

The children included in the study should be: working children, their work place is located in areas of great Cairo, Egypt, their ages ranged from 5-17 years and their parents should consent for participating in the study.

\section{Exclusion criteria:}

Working persons below 5 or above 17 years weren't included in the study. In addition to children whose legal guardians didn't give consent for participating in the study.

\section{- Study questionnaire:}

The questionnaire template including 10 survey questions was prepared by the researchers and was distributed to children and their families, who was interviewed by the researchers about these questions after informed consent taken from children legal guardians. Children were asked directly and their answers were written by the researcher himself. N.B The questionnaires in which participants did not answer all questions or didn't show interest about questions were excluded.

The study was conducted on 647 children, and then 47 children were excluded due to either they didn't show interest or didn't complete all questions.

Questions included in these questionnaires were about demographic data, parents or caregivers' information, abuse type and frequency.

\section{- Ethical consideration}

The study was approved by the Ethical Committee of the Faculty of Medicine, Misr University of sciences and technology (MUST), Cairo, Egypt.

\section{- Statistical analysis}

The Statistical Program SPSS for Windows version 13 was used for data entry and analysis. Quantitative data were presented by mean and standard deviation, while qualitative data were presented by frequency distribution. Chi-square test was used to assess the significant difference between variables. 


\section{RESULTS \\ - Socio-demographic}

characteristics:

Of total 600 children included in the present study; 357 (59.5\%) were males and $243(40.50 \%)$ were females; their age was from 5 to 17 years. Children aged 11-15 years make up $81 \%$ of the sample, while children aged $16-17$ years were $18.83 \%$ of working children. Males were more likely to join labor and age group from 11 to 15 years is the most significant age to join labor (table 1).

There was a significant difference between working children with regard to parental education, with $45.67 \%$ of working children's mothers and $48.67 \%$ of fathers were joined secondary school. In contrast, only $26 \%$ of working children were registered in schools compared to $68 \%$ noneducated. Working children whom Parents were still married significantly representing about $(81.83 \%$ ) while $13.33 \%$ of parents were divorced (Table 1 ).

Approximately $31 \%$ of working children have 3 brothers and sisters compared to $46 \%$ have less. In addition about 461 (76.83\%) working children were reported to live with both mother and father (Table 1). Most children live in flat (56\%) while refuge and no house were $18 \%$ and $26 \%$, respectively (Table 1 ).

According to child health status; about $70.50 \%$ of working children were healthy while $18.50 \%$ and $11 \%$ has deformity and chronic diseases, respectively (Table 1 ).

\section{- Regarding type of}

occupations and abuse in working

children :

According to nature of work; the majority of working children were employed as peddler $(33.33 \%)$, followed by Garage guard $(16.67 \%)$ and lowest proportion of children employed as Building concierge (3.33\%) (Table 2).

According to exposure to different types of abuse; about $24 \%$ of working children suffered from physical abuse, $54 \%$ suffered from emotional abuse, while $15 \%$ suffered from negligence and only $7.5 \%$ experienced sexual abuse (Table 3).

In regards to form or type of physical abuse; approximately $38 \%$ of working children suffer pushing, 31.2\% experienced to be beaten, 3.55\% Thrown Out, $23.4 \%$ Manhandled, While $2.8 \%$ Beaten and Pushed (Table 4). For emotional maltreatment or emotional abuse, the majority (87.6\%) was insulted while the lower percentages were threaten and insulted; Despise and Insulted both were (0.31\%) (Table 5).

According to neglect abuse, about $43 \%$ of working children subjected to denied food serving by guardian, while about $57 \%$ subjected to denied treatment (Table 6), while for sexual abuse; $2.22 \%$ of Working children was raped, $64.4 \%$ was sexually threatened, and $33.3 \%$ was molested (Table 7).

\section{- The relation between child abuse types and Socio-demographic characteristics}

The prevalence of abuse of children working in the Great Cairo area has been verified and there was a statistically significant difference between the different types of abuse of children in Great Cairo area and their early work. This was verified by finding the Chi-Square of abuse patterns as in Table 8. In addition, there was significant correlation between type of work and abuse where children working as peddler, garage guard and House keeper were mostly abused. 
Furthermore, level of parents' education showed significant correlations with types of abuse, where physical abuse

Table (1): Socio-demographic characteristics of the working children Great Cairo, Egypt, during

January-June 2018

\begin{tabular}{|c|c|c|c|}
\hline \multicolumn{2}{|c|}{ Demographic Information } & $\mathbf{N}$ & $\%$ \\
\hline \multirow{3}{*}{ Gender } & Male & 357 & 59.50 \\
\hline & Female & 243 & 40.50 \\
\hline & Total & 600 & 100.00 \\
\hline \multirow{4}{*}{ Age Group } & 5-10 Years & 1 & 0.17 \\
\hline & 11-15 Years & 486 & 81.00 \\
\hline & 16-17 Years & 113 & 18.83 \\
\hline & Total & 600 & 100.00 \\
\hline \multirow{5}{*}{ Mothers $^{\text {ee }}$ Education } & No formal education & 83 & 13.80 \\
\hline & Primary school & 148 & 24.67 \\
\hline & Secondary school & 274 & 45.67 \\
\hline & University & 95 & 15.83 \\
\hline & Total & 600 & 100.00 \\
\hline \multirow{6}{*}{ Fathers $^{e e}$ Education } & No formal education & 45 & 7.50 \\
\hline & Primary school & 145 & 24.17 \\
\hline & Secondary school & 292 & 48.67 \\
\hline & University & 109 & 18.17 \\
\hline & Others & 9 & 1.50 \\
\hline & Total & 600 & 100.00 \\
\hline \multirow{5}{*}{ Parents marital status } & Married & 491 & 81.83 \\
\hline & Divorced & 80 & 13.33 \\
\hline & Pass away & 27 & 4.50 \\
\hline & Unknown & 2 & 0.33 \\
\hline & Total & 600 & 100.00 \\
\hline \multirow{5}{*}{ Guardian } & Mother \& Father & 461 & 76.83 \\
\hline & Father & 30 & 5.00 \\
\hline & Mother & 78 & 13.00 \\
\hline & Others & 31 & 5.17 \\
\hline & Total & 600 & 100.00 \\
\hline \multirow{3}{*}{ Education } & In Education & 192 & 32.00 \\
\hline & Non educated & 408 & 68.00 \\
\hline & Total & 600 & 100.00 \\
\hline \multirow{7}{*}{ No of siblings } & One & 111 & 18.50 \\
\hline & Two & 165 & 27.50 \\
\hline & Three & 186 & 31.00 \\
\hline & Four & 93 & 15.50 \\
\hline & Five & 18 & 3.00 \\
\hline & $>$ five & 27 & 4.50 \\
\hline & Total & 600 & 100.00 \\
\hline \multirow{4}{*}{ Housing data } & Flat & 336 & 56.00 \\
\hline & Refuge & 108 & 18.00 \\
\hline & No house & 156 & 26.00 \\
\hline & Total & 600 & 100.00 \\
\hline \multirow{4}{*}{ Child health status } & Healthy & 423 & 70.50 \\
\hline & Infirmity/ deformity & 111 & 18.50 \\
\hline & Chronic disease & 66 & 11.00 \\
\hline & Total & 600 & 100.00 \\
\hline
\end{tabular}

was prominent in cases of non- or loweducated parents (table8). 
Table (2): Different occupations of children work

\begin{tabular}{|c|c|c|}
\hline Occupation & Number & $\%$ \\
\hline Car wash & 50 & 8.33 \\
\hline Labour-force & 21 & 3.50 \\
\hline Mechanic & 24 & 4.00 \\
\hline Saloon & 5 & 0.83 \\
\hline peddler & 200 & 33.33 \\
\hline Garage guard & 100 & 16.67 \\
\hline Car mechanic assistant & 50 & 8.33 \\
\hline waiter & 38 & 6.33 \\
\hline Building concierge & 20 & 3.33 \\
\hline House keeper & 92 & 15.33 \\
\hline Total & 600 & 100.00 \\
\hline
\end{tabular}

Table (3): Types of abuse in working children at Great Cairo, Egypt, during January-June 2018

\begin{tabular}{|l|c|c|}
\hline \multicolumn{1}{|c|}{ Types of abuse } & $\mathbf{N}$ & \% \\
\hline physical abuse & 141 & 23.50 \\
\hline emotional abuse & 324 & 54.00 \\
\hline Negligence abuse & 90 & 15.00 \\
\hline Sexual abuse & 45 & 7.50 \\
\hline Total & 600 & 100.00 \\
\hline
\end{tabular}

Table (4): Physical abuse types

\begin{tabular}{|l|c|c|}
\hline \multicolumn{1}{|c|}{ Types of physical abuse } & N & \% \\
\hline Beaten & 44 & 31.21 \\
\hline Thrown Out & 5 & 3.55 \\
\hline Pushed & 54 & 38.30 \\
\hline Manhandled & 33 & 23.40 \\
\hline Beaten and Pushed & 4 & 2.84 \\
\hline Beaten and Manhandled & 1 & 0.71 \\
\hline Total & 141 & 100.00 \\
\hline
\end{tabular}

Table (5): Types of Emotional abuse

\begin{tabular}{|l|c|c|}
\hline \multicolumn{1}{|c|}{$\begin{array}{c}\text { Types of emotional } \\
\text { abuse }\end{array}$} & N & \% \\
\hline Threaten & 13 & 4.01 \\
\hline Despise & 16 & 4.94 \\
\hline Insulted & 284 & 87.65 \\
\hline Threaten and Insulted & 9 & 2.78 \\
\hline Threaten and Despise & 1 & 0.31 \\
\hline Despise and Insulted & 1 & 0.31 \\
\hline Total & 324 & 100.00 \\
\hline
\end{tabular}


Table (6): Types of negligence

\begin{tabular}{|l|c|c|}
\hline $\begin{array}{c}\text { Types of negligence } \\
\text { abuse }\end{array}$ & N & \% \\
\hline Denied food & 39 & 43.33 \\
\hline Denied treatment & 51 & 56.67 \\
\hline Total & 90 & 100.00 \\
\hline
\end{tabular}

Table (7): Types of sexual abuse

\begin{tabular}{|l|c|c|}
\hline \multicolumn{1}{|c|}{ Types of sexual abuse } & $\mathbf{N}$ & \% \\
\hline Raped & 1 & 2.22 \\
\hline Sexual threat & 29 & 64.44 \\
\hline Molested & 15 & 33.33 \\
\hline Total & 45 & 100.00 \\
\hline & & \\
\hline
\end{tabular}

\section{DISCUSSION}

In this study, the age group 11-17 years was significantly associated with joining the work; also the illiteracy rate among children and the low educational levels of their parents have been strongly related to child labor. These findings are consistent with the findings of Hadi, (2000), in his study of 3809 children between the ages of 10 and 14 living in 150 villages in two rural provinces of Bangladesh.

Furthermore, it was proved by Mohammed et al., (2014), that the age group of 12-17 years was significantly associated with joining a job

In the present study, children from large families with two (27\%) and three siblings (31\%) were more likely to participate in the work. Also, only $26 \%$ of working children were registered in schools compared to $68 \%$ non-educated.

These results were consistent with the results of Patrinos and Psacharopoulos, (1997), which showed that the larger the household, the lower the likelihood that the child would be in school and more child labor.
In addition, the current study showed that the most common forms of abuse were emotional abuse (54\%) followed by physical abuse (24\%), negligence abuse (15\%) then sexual abuse (7.5\%). This finding can be interpreted on the basis that psychological abuse is one of the most common forms of abuse in all societies on their cultural and ethnic differences (Gilbert, 1997). Also, Moran et al., (2002), noted that the pattern of psychological abuse is the basis or source of other abuse patterns.

In addition, psychological abuse is considered as a latent pattern in all patterns of child abuse, and it is the destructive force in all patterns of child abuse. It is more harmful to the child than physical abuse because children are subjected to physical abuse sporadically while Psychological abuse is always experienced (Glaser, 2002). 
Table (8): the relation between child abuse types and Socio-demographic characteristics

\begin{tabular}{|c|c|c|c|c|c|c|c|c|c|c|c|c|c|}
\hline & \multicolumn{2}{|c|}{$\begin{array}{c}\text { Types of } \\
\text { physical } \\
\text { abuse } \\
(n=141)\end{array}$} & \multicolumn{2}{|c|}{$\begin{array}{c}\text { Types of } \\
\text { emotional } \\
\text { abuse } \\
(n=324) \\
\end{array}$} & \multicolumn{2}{|c|}{$\begin{array}{c}\text { Types of } \\
\text { negligence } \\
\text { abuse } \\
(\mathbf{n}=90) \\
\end{array}$} & \multicolumn{2}{|c|}{$\begin{array}{c}\text { Types of } \\
\text { sexual } \\
\text { abuse } \\
(n=45) \\
\end{array}$} & \multicolumn{2}{|c|}{ Total $(n=600)$} & \multicolumn{2}{|c|}{ Chi-Square } \\
\hline & & $\mathbf{N}$ & $\%$ & $\mathbf{N}$ & $\%$ & $\mathbf{N}$ & $\%$ & $\mathbf{N}$ & $\%$ & $\mathbf{N}$ & $\%$ & $X^{2}$ & $\begin{array}{c}\text { P- } \\
\text { value }\end{array}$ \\
\hline \multirow{3}{*}{ Gender } & Male & 117 & 82.98 & 175 & 54.01 & 50 & 55.56 & 15 & 33.33 & 357 & 59.5 & \multirow{3}{*}{49.671} & \multirow{3}{*}{$\begin{array}{c}<0.001 \\
*\end{array}$} \\
\hline & Female & 24 & 17.02 & 149 & 45.99 & 40 & 44.44 & 30 & 66.67 & 243 & 40.5 & & \\
\hline & Total & 141 & 100 & 324 & 100 & 90 & 100 & 45 & 100 & 600 & 100 & & \\
\hline \multirow{4}{*}{$\begin{array}{c}\text { Age } \\
\text { Group }\end{array}$} & 5-10 Years & 0 & 0.00 & 1 & 0.31 & 0 & 0.00 & 0 & 0.00 & 1 & 0.17 & \multirow{4}{*}{93.677} & \multirow{4}{*}{$\begin{array}{l}<0.001 \\
\quad *\end{array}$} \\
\hline & 11-15 Years & 90 & 63.83 & 308 & 95.06 & 58 & 64.44 & 30 & 66.67 & 486 & 81.00 & & \\
\hline & 16-17 Years & 51 & 36.17 & 15 & 4.63 & 32 & 35.56 & 15 & 33.33 & 113 & 18.83 & & \\
\hline & Total & 141 & 100 & 324 & 100 & 90 & 100 & 45 & 100 & 600 & 100 & & \\
\hline \multirow{5}{*}{$\begin{array}{c}\text { Mothers } \\
\text { ce } \\
\text { Educati } \\
\text { on }\end{array}$} & $\begin{array}{l}\text { No formal } \\
\text { education }\end{array}$ & 63 & 44.68 & 7 & 2.16 & 9 & 10.00 & 4 & 8.89 & 83 & 13.83 & \multirow{5}{*}{$\begin{array}{c}235.18 \\
8\end{array}$} & \multirow{5}{*}{$\begin{array}{c}<0.001 \\
*\end{array}$} \\
\hline & $\begin{array}{l}\text { Primary } \\
\text { school }\end{array}$ & 46 & 32.62 & 48 & 14.81 & 38 & 42.22 & 16 & 35.56 & 148 & 24.67 & & \\
\hline & $\begin{array}{c}\text { Secondary } \\
\text { school } \\
\end{array}$ & 28 & 19.86 & 208 & 64.20 & 23 & 25.56 & 15 & 33.33 & 274 & 45.67 & & \\
\hline & University & 4 & 2.84 & 61 & 18.83 & 20 & 22.22 & 10 & 22.22 & 95 & 15.83 & & \\
\hline & Total & 141 & 100 & 324 & 100 & 90 & 100 & 45 & 100 & 600 & 100.00 & & \\
\hline \multirow{5}{*}{$\begin{array}{c}\text { Fathers } \\
\text { ee } \\
\text { Educati } \\
\text { on }\end{array}$} & $\begin{array}{l}\text { No formal } \\
\text { education }\end{array}$ & 20 & 14.18 & 15 & 4.63 & 15 & 16.67 & 4 & 8.89 & 54 & 9.00 & \multirow{5}{*}{$\begin{array}{c}171.23 \\
6\end{array}$} & \multirow{5}{*}{$\begin{array}{l}<0.001 \\
\quad *\end{array}$} \\
\hline & $\begin{array}{c}\text { Primary } \\
\text { school }\end{array}$ & 71 & 50.35 & 28 & 8.64 & 20 & 22.22 & 26 & 57.78 & 145 & 24.17 & & \\
\hline & $\begin{array}{c}\text { Secondary } \\
\text { school } \\
\end{array}$ & 49 & 34.75 & 196 & 60.49 & 40 & 44.44 & 7 & 15.56 & 292 & 48.67 & & \\
\hline & University & 1 & 0.71 & 85 & 26.23 & 15 & 16.67 & 8 & 17.78 & 109 & 18.17 & & \\
\hline & Total & 141 & 100 & 324 & 100 & 90 & 100 & 45 & 100 & 600 & 100.00 & & \\
\hline \multirow{11}{*}{$\begin{array}{c}\text { Occupat } \\
\text { ion }\end{array}$} & Car wash & 15 & 10.64 & 25 & 7.72 & 9 & 10.00 & 1 & 2.22 & 50 & 8.33 & \multirow{11}{*}{$\begin{array}{c}142.87 \\
9\end{array}$} & \multirow{11}{*}{$\begin{array}{c}<0.001 \\
*\end{array}$} \\
\hline & $\begin{array}{c}\text { Labour- } \\
\text { force }\end{array}$ & 4 & 2.84 & 14 & 4.32 & 2 & 2.22 & 1 & 2.22 & 21 & 3.50 & & \\
\hline & Mechanic & 7 & 4.96 & 13 & 4.01 & 3 & 3.33 & 1 & 2.22 & 24 & 4.00 & & \\
\hline & Saloon & 1 & 0.71 & 2 & 0.62 & 1 & 1.11 & 1 & 2.22 & 5 & 0.83 & & \\
\hline & Peddler & 57 & 40.43 & 123 & 37.96 & 15 & 16.67 & 5 & 11.11 & 200 & 33.33 & & \\
\hline & $\begin{array}{c}\text { Garage } \\
\text { guard }\end{array}$ & 10 & 7.09 & 72 & 22.22 & 15 & 16.67 & 3 & 6.67 & 100 & 16.67 & & \\
\hline & $\begin{array}{c}\text { Car } \\
\text { mechanic } \\
\text { assistant }\end{array}$ & 2 & 1.42 & 33 & 10.19 & 13 & 14.44 & 2 & 4.44 & 50 & 8.33 & & \\
\hline & Waiter & 5 & 3.55 & 15 & 4.63 & 15 & 16.67 & 3 & 6.67 & 38 & 6.33 & & \\
\hline & $\begin{array}{c}\text { Building } \\
\text { concierge }\end{array}$ & 12 & 8.51 & 5 & 1.54 & 1 & 1.11 & 2 & 4.44 & 20 & 3.33 & & \\
\hline & $\begin{array}{l}\text { House } \\
\text { keeper }\end{array}$ & 28 & 19.86 & 22 & 6.79 & 16 & 17.78 & 26 & 57.78 & 92 & 15.33 & & \\
\hline & Total & 141 & 100 & 324 & 100 & 90 & 100 & 45 & 100 & 600 & 100.00 & & \\
\hline
\end{tabular}

* $P$-value $<0.001=$ Statistical significance

The current study showed that majority of working children were healthy $(70 \%)$ making them able to perform their work. In contrast many studies showed higher prevalence of health complaints among working children, however, these studies

Egypt J. Forensic Sci. Appli. Toxicol. 
relay health problems on work burden and low socioeconomic status (Mohammed et al., 2014). El-Gilany et al., (2007), observed increased risks of physical disorders including back pain, fatigue, chronic diarrhea, bronchial asthma, skin problems, and chronic headache for working compared to non-working students. Also Noweir et al., (1993) reported that young workers had significantly higher prevalence of the following manifestations compared to controls: respiratory, cardiovascular, gastrointestinal and neuropsychiatric complaints; and other health problems including backache, hernia and nocturnal enuresis.

\section{CONCLUSIONS}

The study concluded that working children are more vulnerable to many abuses and abusive practices from employers. Poverty, illiteracy of parents, large numbers of families, and absence of fathers or unemployment are the driving forces of child labor in the Great Cairo governorate.

\section{REFERENCES}

Ali, F.R.M. (2019): The Journal of Development Studies, 55(5), pp.845858. Available at: https://www.tandfonline.com/doi/full/10 .1080/00220388.2018.1438595.

EL-Gendy, I.S.; EL- Kholy, S.M.S.; Metwally, E.S. \& Mohamed, O.R. (2016): The Egyptian Journal of Forensic Sciences and Applied Toxicology, 16(1), pp.115-129. Available at: https://ejfsat.journals.ekb.eg/article_399 56.html.

El-Gilany, A.H.; Khalil, I.A.H. \& ElWehady, A. (2007): Eastern Mediterranean health journal $=L a$ revue de sante de la Mediterranee orientale $=$ al-Majallah al-sihhiyah lisharq al-mutawassit, 13(2), pp.347-63. Available http://www.ncbi.nlm.nih.gov/pubmed/1 7684857.

Elsaied, H. \& Alsehly, A. (2017): Egyptian Journal of Psychiatry, 38(2), p.120. Available at: http://new.ejpsy.eg.net/text.asp?2017/38 /2/120/209674.

Gilbert, N. (1997): Combating child abuse, international perspective, and Trends; Oxford University Press Inc: New York.

Glaser, D. (2002): Child Abuse \& Neglect, 26(6-7), pp.697-714. Available at: https://linkinghub.elsevier.com/retrieve/ pii/S0145213402003423.

Hadi, A. (2000): Public health, 114(5), pp.380-4. Available at: http://www.ncbi.nlm.nih.gov/pubmed/1 1035460.

Hindman, H.D. (2009): The world of child labor: An historical and regional survey. 1st ed.; Routledg.

Homaie Rad, E.; Gholampoor, H. \& Jaafaripooyan, E. (2015): Iranian journal of public health, 44(9), pp.1244-52. Available at: http://www.ncbi.nlm.nih.gov/pubmed/2 6587499.

Mohammed, E.S.; Ewis, A.A.A. \& Mahfouz, E.M. (2014): International Journal of Public Health, 59(4), pp.637-644. Available at: http://link.springer.com/10.1007/s00038 -014-0559-5.

Moran, P.M.; Bifulco, A.; Ball, C.; Jacobs, C. et al. (2002): Bulletin of the Menninger Clinic, 66(3), pp.213-40. Available at: http://www.ncbi.nlm.nih.gov/pubmed/1 2448628.

Noweir, M.B.; Osman, H.A.; Abbas, F.I.; Abou-Taleb, A.M. et al. (1993): The Journal of the Egyptian Public Health Association, 68(3-4), pp.443-67. Available at: http://www.ncbi.nlm.nih.gov/pubmed/1 7265656.

Patrinos, H.A. \& Psacharopoulos, G. 
(1997): Journal of Population Economics, 10(4), pp.387-405. Available at: http://link.springer.com/10.1007/s00148 0050050.

Elbendary radwan, R., farrag, I., farag, H., Bayoumi, A. (2019). 'A RETROSPECTIVE STUDY OF CHILD DEATHS AMONG CASES REFERRED TO THE EGYPTIAN FORENSIC MEDICINE AUTHORITY DURING THE PERIOD FROM JANUARY TO DECEMBER 2016.', The Egyptian Journal of
Forensic Sciences and Applied Toxicology, 19(4), pp. 65-90. doi: 10.21608/ejfsat.2019.16974.1095

Sealey, B. (2015): Egyptian Journal of Social Work, 1(1), pp.59-77. Available at:

http://ejsw.journals.ekb.eg/article_8836. html.

Shafik, S.; Abd El ghafar, S. \& ELsayed, H. (2019): Journal of Nursing and Health Science, 8(1), pp.41-50. 


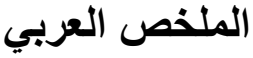

العلاقة الطبية الثر عية بين العنف ضد الأطفال و عمل الطفل في القاهرة الكبري

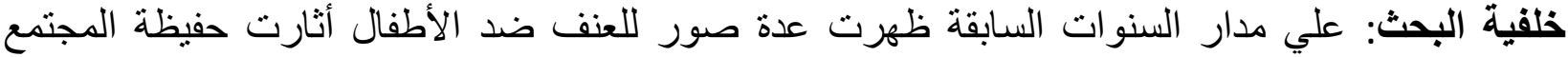
الدولي, ومن هذه الصور: عمل الأطفال و التحرش الجنسي و أضرار النزاعات المسلحة عليهم. لقد أدان

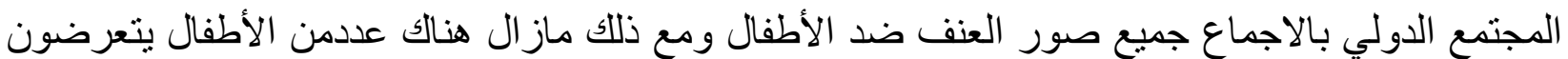
للعنف الجسدي و الجنسي والنفسي في منازلهم ومدارسهم وفي مجتمعاتهم مما يجعل ذللك مؤثرا كارثيا علي الإني صحتهم وكيانهم الحالي و المستقبل.

طريقة البحث: حو الي 600 طفل عامل تم اختيار هم بطريقة عشوائية للمشاركة في البحث ، اعمار هم بين 5 الي 17 سنة وكان الذكور حو الي 357 طفل و الاناث 243 طفل. تم محاورة جميع الطفال المشاركين للاجابة


العنف البدني او النفسي او الجنسي.

نتيجة البحث: بينت الدراسة ان معظم الأطفال المشاركين كانو ا غير متعلمين و معظم ابائهم و أمهاتهم في درجات تعليمية منخفضة. كم كانت اعمار اغلب المشاركين بين 11 و 17 سنة وكانت وظيفة البائع المتجول اكثر وظيفة يعمل بها الأطفال ثم وظيفة عامل جر اج. كما اثتت الدراسة ان حوالي 54 \% من الأطفال العاملين يتعرضون للايذاء النفسي و 24 \% يتعرضون للعنف البدني و 15 \% ينعرضون للاهمال و 7.5 \% تعرضوا للتحرش الجنسي.

الاستتتاج: لقد استنتجت الدراسة أن الأطفال العاملين أكثر عرضة للعنف بأنواعه وان جهل الأباء والأطفال أنفسهم بالاضافة لزيادة عدد افر اد الأسرة هم من اهم العو امل الدافعة لعمل الأطفال. 